\title{
PANCASILA: Local Indigenous Islamic Character Education In Indonesia
}

\author{
Zulkarnaen Dali \\ State Institute for Islamic Studies (IAIN) Bengkulu \\ Jl. Raden Fatah Pagar Dewa Bengkulu, Sumatra, Indonesia \\ E-mail: zulkarnaendali@gmail.com
}

\begin{abstract}
Pancasila: Local Indigenous Islamic Character Education In Indonesia. The diversity of values in Pancasila is the basic capital for character education as the basis of the strength of the character of the Indonesian. The paper seeks to set up an Islamic character education based on the Pancasila-digging theological values of Islam with the values of local traditions, cultures and customs of the archipelago. This study is very important given the fact that so far the character, structure, and methods of character education are too oriented to the West by forgetting even ignoring the ideology and values of the Nusantara character. The approach in this study is descriptive literature review. By transmitting Pancasila's values in family life to children, it will make the children make Pancasila's views as a teaching doctrine, dogma or philosophy that must be practiced in the life of society. Pancasila's revitalization and re-actualization as a philosophical and ideological foundation of the implementation of the character education system in Indonesia, including the implementation of national character education, cannot be negotiable. This is so that Pancasila can be actualized in everyday life within the family, school, community and in the life of nation and state as an educational process.
\end{abstract}

Keywords: Pancasila; character education; Islam.

\begin{abstract}
Abstrak: Pancasila: Local Indeginous Pendidikan Karakter Islam di Indonesia. Keragaman nilai dalam Pancasila merupakan modal dasar bagi pendidikan karakter sebagai basis kekuatan karakter bangsa Indonesia. Paper ini berupaya mendudukkan pendidikan karakter Islam yang berbasiskan Pancasila—menggali nilai-nilai Islam teologis dengan nilai-nilai tradisi lokal, budaya dan adat istiadat nusantara. Kajian ini sangat penting dilakukan mengingat fakta bahwa selama ini sumber, struktur, dan metode pendidikan karakter terlalu berorientasi ke Barat dengan melupakan bahkan mengacuhkan ideologi dan nilai-nilai karakter Nusantara. Pendekatan dalam kajian ini adalah literature review—-konseptual deskriptif. Dengan menularkan nilai-nilai Pancasila dalam kehidupan berkeluarga kepada anak, akan membuat anak menjadikan pandangan Pancasila sebagai ajaran ajaran, dogma atau falsafah yang harus diamalkan dalam kehidupan bermasyarakat. Revitalisasi dan reaktualisasi Pancasila sebagai landasan filosofis dan ideologis pelaksanaan sistem pendidikan karakter di Indonesia, termasuk pelaksanaan pendidikan karakter bangsa, tidaklah bisa ditawar-tawar. Hal ini agar Pancasila dapat teraktualisasi dalam kehidupan seharihari dalam lingkungan keluarga, sekolah, masyarakat dan dalam kehidupan berbangsa dan bernegara sebagai suatu proses pendidikan.
\end{abstract}

Kata kunci: Pancasila; pendidikan karakter; Islam.

\section{Introduction}

Today the issue of moral quality is a very serious problem or acute illness that is always attached to human beings, whenever and wherever. Likewise among learners who must have strong character and personality, but the fact shows moral decadence in their attitudes and behaviors. Starting from motor gangs fights or brawls both men and women, alcoholic beverages, even up to free sex and abortion. In 2014,
State Ministry for Population/National (BKKBN) reported data that 46 percent of adolescents aged 15-19 years had sex. National Census data released in 2014 also shows, 48-51 percent of pregnant women are teenagers. ${ }^{1}$ This brings us all to be able to intensively organize "character education," because character education is

' State Ministry for Population/National (BKKBN), http:// www.bkkbn.go.id/, accessed January 10, 2016. 
geared towards providing preventative and interventional values in character values that must be understood and actualized by learnerssuch as religiosity, honesty, tolerance, discipline, hard work, independent, democratic, homeland love, responsibility and so on.

Likewise, it appears that there is a tendency to abandon local cultures or wisdom and shift to western culture, it appears in fashion, art and entertainment activities, how to interact with children and parents as well as student interactions with teachers, hedonic culture and so on. Indeed, the valueof cultural nobility that has been owned by Indonesian society is an invaluable asset and potential for the development and advancement of Indonesian civilization. The essence of progress achieved by various nations in the world suggests that the development of a nation's character cannot be separated from the cultural aspects and character of the nation's own people. South Korea is a nation that is proud of its success in digging the noble values reflected in the spirit of the Semaul Undong, as is China with the spirit of Confucianism, and Germany with its Protestant ethics. ${ }^{2}$

Exploring local culture or wisdom is a chosen strategic move to conduct filtration on the increasingly uncontrolled western culture and also as a transnational force for the achievement of Indonesian civilization. The praxis of the values of cultural nobility or local wisdom in Indonesia cannot be separated from harmonious relations with religion, because as a nation that places Pancasila as a nation's philosophy with the first "divine superiors", it will give the logical-praxisical consequences that this nation has the principle of tawhîd and religious vision by still respecting and seeing the cultural roots of the nation. It should also be understood that the birth of Pancasila is the fruit of effort from digging Indonesian cultural wisdom.

Islamic religion, for example, since its arrival on the Indonesian archipelago, as far as it is concerned with the spread of its religion and

${ }^{2}$ Wagiran, "Pengembangan Karakter Berbasis Kearifan Lokal Hamemayu Hayuning Bawana: Identifikasi Nilai-nilai Karakter Berbasis Budaya", Jurnal Pendidikan Karakter Vol. 2, October 3, 2012, pp.329-330. the culture of culture, has indeed shown its hospitality. The point is that Islam is spread in peace, not forcing other converts to embrace Islam, appreciating existing and developing cultures, and even accommodating into local culture and staying with their identity. ${ }^{3}$ It turns out that this tolerant attitude attracted sympathy from the Indonesian people at that time to embrace Islam. In the meantime, Walisongo is a very powerful architect in the Islamization in Indonesia. ${ }^{4}$

Based on the findings of fact and construction of the above thought, this article seeks to inculcate Pancasila based Islamic character education-digging theological values of Islam with the values of local traditions, cultures and customs of the archipelago. This study is very important given the fact that so far the character, structure, and methods of character education are too oriented to the West by forgetting even ignoring the ideology and values of the nusantara character. The approach in this study is descriptive literature review.

\section{Islam and Character Education}

Etymologically, the word character comes from the Greek word charassein meaning to engrave, drawing people on paper or sculpting stones. From that sense, the character is then interpreted as a sign or characteristic and therefore gives birth to a view that the character is a pattern or behavior of an individual and a moral state. In the view of Michael Novak a contemporary philosopher, the character is a mixture of all the virtues derived from the religious traditions, stories, and opinions of the wise. ${ }^{5}$

${ }^{3}$ Ali Murfi, "Islam Nusantara: Religion Dialectic and Cultural for Pluralism and Democratic Society", KnE Social Science \& Humanities. p. 46. DOI: 10.18502/kss.v3i5-2324, accessed July 8, 2016.

${ }^{4}$ Ahmad Hilmy Hasan, "Dasar Epistemologi dan Konsep Islam Nusantara; dari NU untuk Dunia”, https://hilmyelhasan95. wordpress.com/2015/12/14/dasar-epistemologi-islamnusantara-dari-nu-untuk-dunia/, accessed January 9, 2016.

${ }^{5}$ Kevin Ryan dan Karen E. Bohlin "Building Character in Schools: Practical Ways to Bring Moral Instructions to Life"Thomas Lickona "Educating for Character: How Our School Can Teach Respect and Responsibility", in Ajat Sudrajat "Mengapa Pendidikan Karakter? ", Jurnal Pendidikan Karakter Vol. 1, No. 2, October, 2011, pp. 48-49. 
In the perspective of Islam through the Quran has explained this character by using the term "morality" as already read in various verses of the Quran and Hadith. Because morality is a plural form of "khuluq" that is morally or "ethics" which means a habit and deed that continues to be repeated. Ibn Mandzhur in the book "Lisânul Arab" says that the word "khuluq" is good in his letters when it comes to dhammah or sukun containing the meaning of al-dîen (belief), althab'u (character), and al-sijiyyat (character) which basically means the feelings of a person's psyche, instincts, traits, and special meanings that are displayed in real or apparent behavior, good or bad, expressing awards or reproach. ${ }^{6}$ In fact, Mahfudz Ali Azzam says almost all Arabic dictionaries agree to define al-khuluq as a condition of a strong sense of spirit to create actions without the need for thought and ideas. ${ }^{7}$

The Quran has given serious and profound attention to character education; Fazlur Rahman also said that the fundamentals of the Quranic teachings and messages are "morals" that emit their gravity in monotheism and social justice. Moral law cannot be changed and it is God's command that humans cannot even make moral law. Humans must always submit to and obey God, submission and obedience is "Islam" and Islamic actualization in life is called worship or devotion to Allah Swt ${ }^{8}$ Asy-SyauqiBey, a famous arabic poet, in his poem "innamal umamul akhlâqu mâbaqiyat $\checkmark$ fain hummû dzahabat akhlâquhum dzahabû", indeed a community is only in accordance with his existing morals. So when there is no morality, the people disappear.

Given the central position of moral character in man then one of the main mission of Rasulullah

${ }^{6}$ Abu al-Fadhl Jamâluddin Ibnu Mandzhur al-Anshary, "Lisân al-Arab", in Amri Rahman and Dulsukni Kasim. "Pendidikan Karakter Berbasis Al-Qur'an: Upaya menciptakan Bangsa yang Berkarakter”, Al-Ulum Vol. 14, No. 1, June, 2014, pp. 224-225.

7 Mahfudz Ali Azzam, "al-Akhlâq fi al-Islam Baina alNadzhariyyatwa al-Thathbiq", in Amri Rahman and Dulsukni Kasim. "Pendidikan Karakter Berbasis Al-Qur'an: Upaya menciptakan Bangsa yang Berkarakter”, Al-Ulum No. 14, No. 1, June, 2014, p. 225

${ }^{8}$ Fazlur Rahman, "Islam", in Amri Rahman and Dulsukni Kasim. "Pendidikan Karakter Berbasis Al-Qur'an: Upaya menciptakan Bangsa yang Berkarakter”, Al-Ulum No. 14, No. 1, June, 2014, p. 261.
Saw sent by Allah Swt is to perfection the human "akhlâq" (innamâ bu'itstu liutammima makârimal akhlâq) because morality is a symbol or sign of the perfection of the faith of a human (akmalul mu'minîna îmânan ahsanuhum khuluqâ). The success of the main mission of the mission of the Prophet is certainly not only because of the willingness of the mau'idhah hasanah but most importantly is because of the uswatun hasanah, that the Prophet has given exemplary, has adorned himself first with noble and noble character, such as shiddiq, tabligh, trust and fathonah. Therefore Allah Almighty has spoken in Q.S. al-Ahzâb [33]: 21: "Laqad kâna lakum fî rasûlillâhi uswatun hasanah", and also in the personal of the Prophet is the character of the Quran (kâna khuluquhul qurân).

\section{Pancasila as a Character Education Base}

The diversity of values in Pancasila is the basic capital of character education. We no longer need to look for a form of even a character education model because of the power base of the nation's character we have. The Supreme Godhead value in first we can make learning reference some value. The value of tolerance during this time has only become discouraged and difficult to execute due to cessation of cognitive discourse. This results in the weakness of the character of the community. Schools should start to be able to try to decipher them first into value materials in character education. For example, tolerance, respect for other beliefs through interesting game activities.

Fair and Civilized Humanity is an important part of the nation's character chains. Educating fellow human beings is the main capital in social relations. One of the factors in character education is the ability to give appreciation to others. Through practical activities such as rigor, personal hygiene, diligence is a learning process to become civilized. It can be taught through conflict management. Some people see conflict is taboo so conflicts get rid of the realm of learning. In fact, in conflict, we can be human to one another. Conflict does not necessarily mean that anarchists, conflicts can be taught through debate processes and rendering arguments. It is 
important that conflict management education aims to nurture people with mutual respect.

They can be described by Indonesian Association by introducing Indonesian culture physically. Various national cultural outcomes as examples of local wisdom are the gateway to the unity of the unity. The fundamental unity of character is love of the Nation. The process of love of the Land of God is certainly no longer needed in very abstract ways. These characters can be built by building the creativity of students, of course with the still characteristic of regional culture. Student creativity is very close to the ability to understand cognitive (competence). With the help of technology, we can easily identify regional diversity. Not only that, the creativity process is also easier with the help of technology. The Character of Motherland love can be very helpful with the presence of modern tools so that in teaching we even easier and interesting.

Citizenship Led by Wisdom in Consultation / Representatives is the one who is currently a reference to democracy in Indonesia. One interesting issue is that we have a basic democratic value, but cannot be implemented. Fundamental democratic values are fundamental, in accordance with procedures and respect the dignity of others according to conscience. This is what can be conveyed in the learning of student character education. Students are introduced with the correct procedures and according to the applicable rules / principles. This is not to invite students to be obedient, but to invite them to be obedient. Being obedient is part of the discipline so this fourth way can be started by giving self-discipline training to appreciate the process involving others.

Social Justice for All Indonesian People is a very basic social sensitivity base. The human character of one of the indicators is capable of fighting for one another, not for himself. That is what social justice is, social justice does not need to be covered in broader coverage but in the daily activities of the students. Do students have compassion for other students? This is what can be described in everyday learning. It is time for each school to restart Pancasila as a basic reference in shaping student character. It is proven that Pancasila is very rich in values of life that is capable of prospering Indonesian society. Prosperity means free from anarchic actions, free from religious fundamental issues, ethnic radicalism, minority-majority dualism, and a stable and even economy. The only way to realize prosperity is through character education. Once again, of course, character education cannot be reduced to the numeric level. Not necessarily difficult, it only requires the courage of the school to put character education on the student's affiliation domain. Understanding Pancasila will be a basic requirement for every educator.

\section{Pancasila's Creation: A Strategy in the Era of Industrial Revolution 4.0}

At the World Economic Forum's annual meeting held in Davos, Switzerland in January 2016, the highlight is about the fourth industry revolution we are currently facing. Emanuel Dimitrios Hatzakis, in his article The Fourth Industrial Revolution, states that one of the features of the fourth era of industrial revolution is the growing number of technological developments in our lives. ${ }^{9}$ This phenomenon is now increasingly visible in our daily lives. Indeed if we speak of the concept of industrial revolution, then the context used is industrial context, including production, business, market, and so forth. But in this paper I want to bring the concept of industrial revolution into the context of social life because in fact society is also an element of the life industry.

Without we realize, today in our daily lives, we are increasingly immersed in the bustle of technology. In running every activity we hamper never get away from the work we have, either to do work routines in the office or to socialize with others. The rapid development of technology can be easily followed by the Indonesian people. This is evident from the growing number of communication technologies emerging with the increasingly sophisticated features and in a short time has been able to capture customers in an amount that cannot be said a bit.

9 Emmanuel Dimitrios Hatzakis, The Fourth Industrial Revolution, Researchgate, 2016. 
From the increasing use of technology in life, one of the things to look out for is the use of irresponsible technology can have an impact on the destruction of this unity and unity of the nation. There have been numerous events leading up to it, for example: the use of social media (medsos) to spread the radical teachings that potentially injure the nation's Second Generation, it is easy for someone to utter hatred to others through social media, as well as actions extreme like suicide bombings in several places of worship. Even this activity is becoming more uncontrollable because it is so easy to create social media accounts and the growing number of people of this nation who are easily lured by these radical issues. The government did not stay silent in addressing some of these events. But the problem is that the world of technology is a liquid and dynamic world. When the government has tried to block some disturbing social media accounts, then there will be more and more identical new accounts.

Keep in mind that from the previous description, we realize that Pancasila is a unifying nation. From here we can see that all the actions that endanger the unity and unity of the nation, as well as those that have been done by means of technology mean harming Pancasila. Fifth please in our State policy is not just a string of empty words that will only decorate the textbooks. Garuda Pancasila is not just a display that must adorn the walls of each house. What we have to realize is that with the existence of Pancasila all the elements of this nation are very diverse, will be unified including when we are more familiar with using technology in our lives. The higher the use of technology, we should be more united with others because basically technology is created to make our lives better. One thing that is not less important is the basis of the State we have five please. Five represents the odd number. Something included in the odd number category will be more complete if there is an even number. Then, the five in Pancasila will become more complete if we are able to accomplish it by behaving according to the implied messages of the above.

After having a good understanding of Pancasila, the next is how our strategy to culture it to the Indonesian nation. Pancasila can only be loved, "owned" and firmly held as a nation's ideology when it is capable of solving various national social issues. Therefore it is right when Notonagoro ${ }^{10}$ more or less say that "the content of Pancasila can be found through various scientific studies." This view is quite advanced in its time, as it sees Pancasila as an open ideology that continuously experiences dynamics in keeping with the development of its supportive community. The philosophical foundation framework for developing morality in character education is to consider the formation of habits, learning, and modeling. ${ }^{11}$

To achieve that great goal, it takes a number of concepts, steps and stages, including introducing the importance of forming and developing a particular moral attitude. So it takes a strategy how the Pancasila values can be cultured in Indonesian society. The efforts of the Pancasila core culture have been carried out by the UGM National Strategic Research Team (2011 - 2013). From these activities, the research team conducted the Pancasila culture through several studies:

1. Material: discover the material of values to the most strategic Pancasilaan

2. Evaluation: finding the weaknesses and causes of these weaknesses in cultivating Pancasila is also seeking the best practice in society

3. Cultural Media: Find media culture of Pancasila culture that fits the younger generation

4. ICT Media: Find the ICT media of Pancasila's culture that fits the younger generation

5. Communication Environment: get an overview of the communication environment that can be a distraction or ease of transmitting message of Pancasila values to the younger generation.

From this research, various method and model of Pancasila culture to Indonesian young generation. Examples of Pancasila out-of-school (TKB), various Pancasila cultural modules, short

\footnotetext{
${ }^{10}$ Notonagoro,Pancasila, (Jakarta:BinaAksara,1987), p.35.

"Saiful Amin Ghofur, “Merancang Kurikulum Anti Korupsi”, Jurnal Pendidikan Islam Vol. 1, No. 1, 2009, pp. 30-35.
} 
films to Pancasila, Pancasila website, books, souvenirs, scientific papers, and so forth. ${ }^{12}$

\section{Implementation of Pancasila Based Character Education: Family, Society, Nation}

Family is an Islamic social system created through the stages of the soul and the pairs then multiply into multiplicity. In the Quran, surah al-Nisâ' [4] verse 1 is stated:

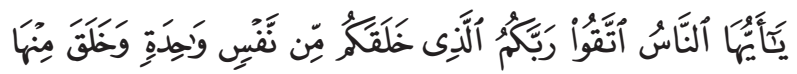

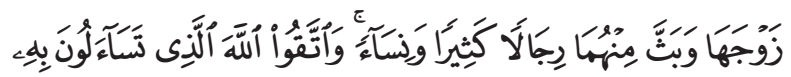

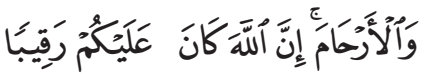

O mankind, fear your Lord Who has created you from one's self, and from Him Allah created his wife; and from both of them God multiplies many men and women. and fear Allah that by His name ye ask one another, and (guard) the bond of peace. Indeed God is always watching and watching over you. (Q.S. al. Nisâ' [4]: 1)

This verse explains that families begin with individuals who are either male or female. After tying themselves through marriage, the family whose total number consists of two persons (husband and wife) is increasing with the presence of two, three or more children. Because it consists of one person then there is a social relationship. In this family it starts all human activities both as individuals and groups. As an individual, humans have a personal duty and responsibility that they must run. As a small group of men have their duties and responsibilities towards that group of families. Each family member is obliged to carry out his duties, functions and responsibilities related to the family. Parents earn a living, protect families, educate their families and provide a sense of security for families. The child is obliged to serve the parents, keep the good name of the family and run all his duties as a child.

The initial foundation of the concept of prayer worship by parents according to Islam is the command of Allah Swt to nurture oneself and the family from the worldly mischief that will

${ }^{12}$ Surono, Pancasila Sebagai Pendidikan Karakter: Sebuah Strategi, Pusat Studi Pancasila Universitas Gadjah Mada, https://www.academia.edu/9602221/, accessed, July 6, 2018 plunge people into hell. In the surah At-Tahrîm [66], verse 6 Allah commands:

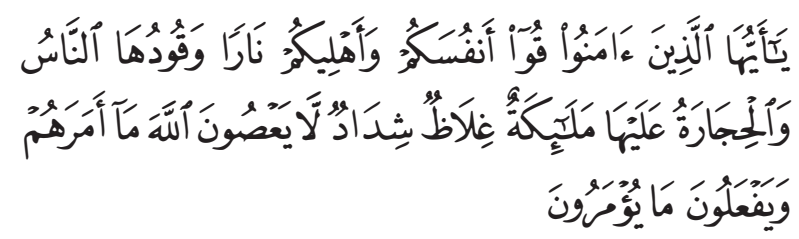

O ye who believe! Guard yourselves and your family from the fire of hell whose fuel is human and stone; the guardians of the abominable, violent angels, and did not disobey God against what He commanded them and always do what was commanded. (Q.S. At-Tahrîm [66]: 6)

The realization of the above order is one of the efforts of educating, guiding and directing the child into a righteous man. They are all in education. Parental responsibility is paramount in comparison with school and community environment in order to make a child a godly person. Husein Mazhariri writes that one of the responsibilities of parents is to teach a child a good talk accompanied by manners and social norms. He adds the need to teach people how to mingle and talk with older people. ${ }^{13}$

From the description above, it can be concluded that parents have a great task and responsibility in educating the child, as the Prophet Saw said above. The word of Rasulullah Saw in a hadith narrated by Bukhari from Abu Khurairah which reads:

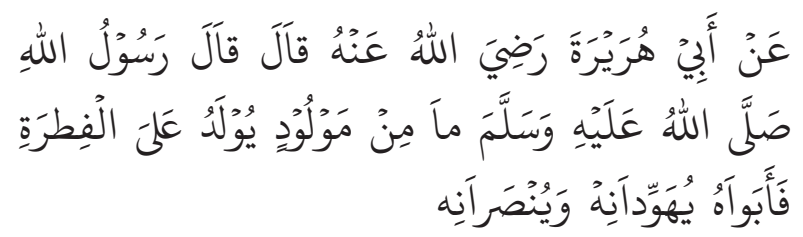

Meaning: From Abu Hurairah r.a said: Rasulullah Saw said: No son born unless born according to his fithrahnya, then both parents are the ones who influence the child to embrace Judaism or embrace Christianity. ${ }^{14}$

Children need education so their nature as God's creatures. So it can be more developed into a human being that is physically and mentally adequate and complete. The first and foremost

${ }^{13}$ Husain Mazhariri, Pintar Mendidik Anak, terjemahan dari Tarbiyah ath-Thift fi ar-Ru'yah al-Islamiyah karya Husain Mazhariri by Segaf Abdillah Yusuf, (Jakarta, Lentera Basritama), 2002, p. 269

${ }^{14}$ Al-Bayan, Terjemah Saheh Bukhari Muslim, (Bandung, Jabal), 2007, p. 36 
institution in educating children to develop their human potential as described above is a family that is also the initial medium that shapes the character, personality and changes in the value of a child. In it there is a process of change from an impotent individual to an individual who acquires basic knowledge of religious values and world life. Without a family role, the child will not be able to become a person who knows his insâniyah. In this regard, the parents are responsible for education, because naturally children in the early days of life are in the middle of their mother and father. The concept of education in this family of first emphasis is the responsibility of parents towards their children and their families. The initial foundation of this concept is the command of Allah Swt to nurture oneself and the family from the worldly misguidance which will plunge people into hell.

In the case of Pancasila Education in the family, the parents are instrumental in introducing the basic philosophy of the country to the child. In the family, parents can tell his son about the philosophical meaning of Pancasila found by Bung Karno in 1945. Pancasila philosophy which basically raises five principles; Godliness, Humanity, Society, Citizenship and Social Justice can be told by parents to their children long before the children know it in school or in the social sphere of the general public. Parents play an active role as a catalyst for Pancasila's high values and can provide examples in everyday life within families and communities.

For example, for example a child asks parents how to deal with diverse religious or racial differences in Indonesia, and parents can explain the reality with Pancasila values that Indonesia is a country that respects the difference whether it is racial, religious, or between groups. In addition, parents can also explain Pancasila so simply through the examples that occur in the social life of the community. For example, an Islamic family can respect and respect other religions in Indonesia such as Christianity, Hinduism or Buddhism in celebrating its Great Days although Islam is the majority religion adopted by $90 \%$ of Indonesian society.

By transmitting Pancasila's values in family life to children, it will make the children make Pancasila's views as a teaching doctrine, dogma or philosophy that must be practiced in the life of society. Departing from this simple example is that Pancasila can be socialized and disseminated to today's children. This education can also be used as a basic education to know the history and greatness of the nation and country of Indonesia. Through this Pancasila, parents can also introduce the motto of Bhinneka Tunggal Ika, the 1945 Constitution, until the basic system of statehood held in Indonesia. Imagine, if every family in Indonesia can do this kind of education in every home, the introduction and practice of Pancasila will soon be possible before the children know in formal education at Elementary School and Junior High School. This makes children more aware of Pancasila because they have been taught by people in the family or home environment.

On November 20-22, 2007 at Quality Hotel Makasar was developed by Training of Trainers (TOT) Project Citizen for junior high school teachers, PPKn junior high school teachers and lecturers Department of East Indonesia's PPKn. This TOT was held in collaboration with Center for Civic Education Indonesia in Jakarta with the Ministry of National Education. At its opening, Director of Center for Civic Education Indonesia, who is an American, stated that he, although not Indonesian, respected and proud of Pancasila as one of the world's great ideologies. According to him, furthermore, Pancasila as the ideology of the Indonesian nation is very comprehensive in terms of the humanity of the humanity of Indonesia, and Pancasila as ideology also has universal values that can be accepted by all the inhabitants of the world. Unfortunately, he said criticisms, why Pancasila tends to appear only in Garuda Pancasila symbols in the walls or office space walls or classroom walls in schools, but less apparent in thought patterns, values, attitudes, commitments, the behavior, and competence of every Indonesian citizen.

Accordingly, revitalizing and actualizing Pancasila as a philosophical and ideological foundation of the implementation of the education system in Indonesia, including the implementation of national character education, 
cannot be negotiable. This is so that Pancasila can be actualized in everyday life within the family, school, community and in the life of nation and state as an educational process. With this kind of thinking framework it is clear that Pancasila is a philosophical and ideological foundation of the implementation of the national education system in the context of national character education.

Pancasila can be a philosophical and ideological foundation in the development of knowledge systems. Here Pancasila has a complete view of the knowledge system. Pancasila ontologists who acknowledge the basis of human nature believe that the source of knowledge is not merely an object of empirical knowledge or rational knowledge alone. According to Pancasila, human beings as knowledge builders and developers have the full knowledge dimensions including: physical knowledge of empirical world, emotional knowledge, intuitive knowledge, rational intellectual knowledge, social knowledge, moral knowledge, and spiritual knowledge. ${ }^{15}$ In a more operational language, this kind of knowledge system is recognized as a result of thought, taste and will, mind, exercise and exercise. Therefore, it is wrong if in the national education system only built intellectual and empirical knowledge alone. Indonesian man according to Pancasila's view is a double dimensional thinking creature but monopluralistic.

Epistemologically, therefore, Pancasila in building such a system of intact knowledge is not merely using the rational truth and empirical truth that is secular through the use of a mere scientific approach or method. Due to the balance of human nature as a monopluralistic creature, Indonesian people build their full knowledge system can also be through imaginative and intuitive approaches and processes that emphasize the sense of taste, a consensus approach that emphasizes social values, reflective approaches that emphasize values of nobility or morals, and a contemplative approach to the inspirational truth that emphasizes spiritual transcendent values. ${ }^{16}$. This is the essence of Indonesian human

${ }^{15}$ Kaelan, Pendidikan Pancasila, (Yogyakarta: Paradigma Yogyakarta, 2006), p. 57

${ }^{16}$ Kaelan, Pendidikan Pancasila..., p. 75 being in its physical and psychological aspects. With the framework of this kind of knowledge philosophy, it is clear that Indonesian people are not regarded only in essence as physical beings and thinkers whose behavior only follows the law of rationality and materialistic law alone. Indonesian people are also creatures that have a sense, intuition, imagination, desire, ideology, ideals, social beings, and even spiritual beings. Thus Pancasila recognizes the essence of humanism-socio-cultural-religious.

How does education in Indonesia carry out its function to form the full Indonesian human character? For this education in Indonesia certainly cannot contradict the constitutional foundation of the Republic of Indonesia that is the 1945 Constitution which is essentially also based on Pancasila. In paragraph IV of the 1945 Constitution, among others it is mentioned that one of Indonesia's national goals is to educate the nation's life. Educating the life of this nation can only be achieved through education, and, therefore, every citizen must obtain equal rights in education. Education in order to educate the nation, based on the Pancasila philosophy above, is not just to intellectual brain development alone. The intelligence referred to in the education program shall include the exercise of faith, the mind, the mind and the will, the mind, and the sport. It is clear that education in order to educate the nation's life includes empowering and enhancing the intelligence of spiritual faith, intellectual or moral intelligence, social intelligence, intellectual intelligence, sense or emotional intelligence, and physical intelligence. This kind of intelligence is called multidimensional intelligence.

The multidimensional nature of this nation's life is essential that every citizen of Indonesia be a good citizen. In Law No. 20/2003 on the National Education System as the foundation for the operationalization of education in Indonesia it is mentioned that the function and purpose of national education to form the good citizen is to develop the ability and form the dignity of the nation and dignity in order to educate the nation's life. The goal is to develop the potential of learners to become believers and to 
be devoted to God Almighty, to be noble, healthy, knowledgeable, capable, creative, independent, and to be a democratic and responsible citizen. It is clear that the purpose of the education is actually also the purpose of character education in Indonesia based on Pancasila. This is because the purpose of education actually forms the full Indonesian human character. Thus, in every educational effort in Indonesia it is also necessary to carry out the character education system.

\section{Conclusion}

The diversity of values in Pancasila is the basic capital of character education. We no longer need to look for a form of even a character education model because of the power base of the nation's character we have. The Supreme Godhead Value in the first place we can make learning reference in the form of tolerance value. Fair and Civilized Humanity is an important part of the nation's character chains. Educating fellow human beings is the main capital in social relations. They can be described by Indonesian Association by introducing Indonesian culture physically. Various national cultural outcomes as examples of local wisdom are the gateway to the unity of the unity. The fundamental unity of character is love of the Nation. Citizenship Led by Wisdom in Consultation / Representatives is the one who is currently a reference to democracy in Indonesia. Social Justice for All Indonesian People is a very basic social sensitivity base. The human character of one of the indicators is capable of fighting for one another, not for himself.

By transmitting Pancasila's values in family life to children, it will make the children make Pancasila's views as a teaching doctrine, dogma or philosophy that must be practiced in the life of society. Pancasila's revitalization and reactualization as a philosophical and ideological foundation of the implementation of the character education system in Indonesia, including the implementation of national character education, can not be negotiable. This is so that Pancasila can be actualized in everyday life within the family, school, community and in the life of nation and state as an educational process.

\section{References}

Ali, Muhammad, Guru dalam Proses Belajar Mengajar, Bandung: Sinar Baru, 1999.

Baso, Ahmad, Islam Nusantara: Ijtihad Jenius \& Ijma' Ulama Indonesia, Jakarta: Pustaka Afid, Jilid 1, 2015.

Budiningsih, Asri C, Pembelajaran Moral, Berpijak Pada Karakteristik Siswa dan Budayanya, Jakarta: Rieneka Cipta, 1999.

Badan Kependudukan dan Keluarga Berencana Nasional, http://www.bkkbn.go.id/, accessed January 10, 2016.

Bayan, Al-, Terjemah Saheh Bukhari Muslim, Bandung, Jabal, 2007

Gunawan, Heri, Kurikulum dan Pembelajaran Pendidikan Agama Islam, Jakarta: Alfabeta, 2012.

Hasan, Ahmad Hilmy, "Dasar Epistemologi dan Konsep Islam Nusantara; dari NU untuk Dunia", https://hilmyelhasan95.wordpress. com/2015/12/14/dasar-epistemologi-islamnusantara-dari-nu-untuk-dunia/, accessed January 9, 2016.

Husain Mazhariri, Tarbiyah ath-Thift fi ar-Ru'yah al-Islamiyah, trans by Segaf Abdillah Yusuf, Pintar Mendidik Anak, Jakarta, Lentera Basritama, 2002.

Idrus, Muhammad, "Pendidikan Karakter pada Kelurga Jawa", Jurnal Pendidikan Karakter Vol. 2, No. 2, June 2012.

Kaelan, Pendidikan Pancasila, Yogyakarta: Paradigma Yogyakarta, 2006.

Muji Santoso, Agus, “Konsep Diri Melalui Pendidikan Berbasis Keunggulan Lokal sebagai Model Pendidikan Berkarakter dan Berbudaya Bangsa di Era Global", Proceedings of the $4^{\text {th }}$ International Conference on Teacher Education; Join Conference UPI \& UPSI Bandung, Indonesia

Murfi, Ali, "Islam Nusantara: Religion Dialectic and Cultural for Pluralism and Democratic Society", KnE Social Science \& Humanities, DOI: 10.18502/kss.v3i5-2324, accessed July 8, 2016.

Poerwanto, Ngalim, Psikologi Pendidikan, Jakarta: Remaja Rosdakarya,2000.

Rahman, Amri and Dulsukni Kasim, "Pendidikan Karakter Berbasis Al-Qur'an: Upaya menciptakan Bangsa yang Berkarakter", Al-Ulum Vol. 14,No. 1, June, 2014. 
Rohman, Muhammad, Kurikulum Berkarakter, Jakarta: Prestasi Pustaka, 2012.

Rosyada, Dede, Paradigma Pendidikan Demokratis, Jakarta: Kencana, 2000.

Ruyadi, Yadi, “Model Pendidikan Karakter Berbasis Kearifan Budaya Lokal: Penelitian terhadap Masyarakat Adat kampung Benda Kerep Cirebon Jawa Barat untuk Pengembangan Pendidikan Karakter di Sekolah", Proceedings of the $4^{\text {th }}$ International Conference on Teacher Education; Join Conference UPI \& UPSI Bandung, Indonesia, November 8-10 2010

Sahal, Akhmad dan Munawir Aziz (ed.), Islam Nusantara: Dari Ushul Fiqh Hingga Paham Kebangsaan, Bandung: Mizan, 2015.

Sudrajat, Ajat, "Mengapa Pendidikan Karakter?", Jurnal Pendidikan Karakter Vo.1, No. 2, October 2011.

Susanto, Edi, “Islam Pribumi Versus Islam Otentik: Dialektika Islam Universal with Partikularitas BudayaLokal”, Karsa Vo. 13, No. 1, April, 2008.
Surono, Pancasila Sebagai Pendidikan Karakter: Sebuah Strategi, Pusat Studi Pancasila Universitas Gadjah Mada, https://www. academia.edu/9602221/, accessed, July 6, 2018 Wagiran, "Pengembangan Karakter Berbasis Kearifan Lokal Hamemayu Hayuning Bawana: Identifikasi Nilai-nilai Karakter Berbasis Budaya", Jurnal Pendidikan Karakter Vo.2, No. 3, October, 2012.

Wahyu Wardhani, Novia, "Pembelajaran NilaiNilai Kearifan Lokal sebagai Penguat Karakter Bangsa Melalui Pendidikan Informal: Studi Deskriptif Kualitatif Tembang Asmarandana dalam Serat Wulang Rehpada Masyarakat Keraton Kasunanan Surakarta", Jurnal Penelitian Pendidikan Vo. 14, No. 1, April, 2013. 